Pak. j. sci. ind. res. Ser. B: biol. sci. 201356 (1) 46-52

\title{
Heavy Metals Contamination in Fish and Shrimp from Coastal Regions of Karachi, Pakistan
}

\author{
Syed Sanower Ali ${ }^{a *}$, Ishratullah Siddiqui ${ }^{b}$, Farooq Ahmed Khan ${ }^{b}$ and Alia Bano Munshi ${ }^{b}$ \\ ${ }^{a}$ Department of Community Health Sciences, Ziauddin University, Karachi, Pakistan \\ ${ }^{\mathrm{b}}$ PCSIR Laboratories Complex, Shahrah-e-Dr. Salimuzzaman Siddiqui, \\ Karachi-75280, Pakistan
}

(received April 26, 2012; revised October 11, 2012; accepted November 13, 2012)

\begin{abstract}
In the present study, the heavy metals $(\mathrm{Pb}, \mathrm{Cu}, \mathrm{Cd}, \mathrm{Fe}, \mathrm{Zn})$ concentration was determined by using atomic absorption spectrophotometer (AAS) in 5 species of fish and 3 species of shrimp commonly taken by locals at the coastal regions of Karachi, Pakistan Concentrations of $\mathrm{Cd}$ and $\mathrm{Pb}$ studied in tissues of Mushka (Otolithes ruber, 0.120 and $1.018 \mu \mathrm{g} / \mathrm{g}$ wet weight) and Palaemon longirostris shrimp (2.457 and $0.480 \mu \mathrm{g} / \mathrm{g}$ wet weight ) were found near to safe level for human consumption. Mullet, Tarli, Surmai, Dohtar fishes and Blacktiger shrimp were found contaminated by $\mathrm{Cd}$ and $\mathrm{Pb}$ but still within the limits fit for and human consumption. The distribution of trace metals detected in all fish and shrimp species followed the order of $\mathrm{Zn}>\mathrm{Pb}>\mathrm{Fe}>\mathrm{Cu}>\mathrm{Cd}$ and $\mathrm{Cd}>\mathrm{Fe}>\mathrm{Zn}>\mathrm{Cu}>\mathrm{Pb}$, respectively. Metal concentration exhibited significant species variation and followed the order in fishes as Otolithes ruber $>$ Liza vaigiensis $>$ Sardinella albella $>$ Scomberomorus guttatus $>$ Pomadasys olivaecum and in shrimp as Palaemon longirostris $>$ Penaeus monodon $>$ Penaeus penicillatu.
\end{abstract}

Keywords: heavy metals, fish, shrimp, tissues, Karachi coast

\section{Introduction}

Heavy metals discharged into the marine environment can damage both marine species diversity and ecosystem due to their toxicity (Turkmen et al., 2009). Heavy metals including essential and non-essential elements have particular significance in ecotoxicology because they are highly persistent and have toxic potential for living organisms (Storelli et al., 2005). These toxic effects of metals and organic contaminants have been well studied at numerous locations throughout Pakistan (Tariq et al., 2007). Fish are often at the top of the aquatic food chain and may contain large amount of some metals from the water (Mansour and Sidky, 2002), making it necessary to determine the levels of certain heavy metals in the fish species and shrimp that are consumed by coastal villagers in order to minimize their health risk. It has been reported that the presence of metals particularly lead $(\mathrm{Pb})$ in certain foods enhances toxicological effect frequencies in man (Levy et al., 1985). For example, cadmium (Cd), lead ( $\mathrm{Pb})$ and mercury $(\mathrm{Hg})$ producing injury to kidneys leading to features of chronic toxicity, including impaired kidney function, poor reproductive capacity, hypertension,

*Author for correspondence; E-mail: dr_ssan@yahoo.com tumors and hepatic dysfunction (Varsha et al., 2010). The limits of metal contaminants particularly in fish and shrimp have led to health concerns for high-risk populations, such as pregnant women and children (EPA, 1989).

International level of $\mathrm{Cd}, \mathrm{Zn}$, and $\mathrm{Cu}$ are given as 3, 50 and $20 \mu \mathrm{g} / \mathrm{g}$ wet wt, respectively by US FDA (1993a) and 1.5, 60, 200 and 3 in marine biota muscle (ppm dry weight) for $\mathrm{Cd}, \mathrm{Cu}, \mathrm{Zn}$, and $\mathrm{Pb}$ (US FDA, 2003). The maximum level of $\mathrm{Cd}$ in fish meat and Crusactean 0.05$1.00(\mathrm{mg} / \mathrm{kg}$ wet weight $)$ and maximum levels of lead in fish has been changed to $0.30 \mathrm{mg} / \mathrm{kg}$ fresh weight by the EU (2006).

Generally residents of our coastal areas are very poor and do not have a good sense of food security therefore, it is the duty of the concerned authorities to focus on this aspect and ensure that food security objectives are incorporated into national poverty reduction strategies. This would have impact at the national, sub-national, household and individual levels with particular emphasis on reducing hunger and extreme poverty (FAO, 1983).

The present study was undertaken to determine the concentration of heavy metals $(\mathrm{Pb}, \mathrm{Cu}, \mathrm{Zn}, \mathrm{Fe}, \mathrm{Cd})$ in 
commonly eaten food of fish and shrimp species of coastal regions of Karachi, Pakistan.

\section{Materials and Methods}

Sampling. All samples of fishes and shrimps were collected from January to December 2011 at a frequency of twice per week.

The most eaten fish were identified as $P$. olivaecum (Dhotar), S. albella (Tarli), L. vaigiensis (Mullet), O. ruber (Mushka), S. guttatus (Surmai) and three species of shrimp P. pencillatus, P. monodon and P. longirostris. Five specimen of each species were collected. The samples were dried in filter paper, packed in pre cleaned polyethylene bags and stored below $-20^{\circ} \mathrm{C}$ prior to further analysis (Yilmaz et al., 2007).

Samples were collected from kitchens of village houses, so all fishes were already washed in their kitchens and in Laboratory these were again washed with de-ionized water before sub sampling.

Sample preparation. The homogenized fish tissues (edible part) and shrimps sample (2 g each) were digested in concentrated $\mathrm{HNO}_{3}(65 \%)$ and $\mathrm{HCl}(35 \%)$ of analytical grade (Merck, Darmstadt, Germany) (Zachariadis et al., 1995). The samples were placed on a hot block for digestion at $70^{\circ} \mathrm{C}$ for $1 \mathrm{~h}$ : before they were fully digested at high temperature $\left(140^{\circ} \mathrm{C}\right)$ for at least $3 \mathrm{~h}$.

The digested samples were then diluted to $50 \mathrm{~mL}$ with de-ionized water and filtered through Whatman No. 42 filter paper.

Standard solution of $\mathrm{Cd}, \mathrm{Pb}, \mathrm{Cu}, \mathrm{Fe}$ and $\mathrm{Zn}$ were prepared from stock solution $(1000 \mu \mathrm{g} / \mathrm{mL})$ Fluka Kamica (Switzerland) of corresponding metal ions. Standard reference material (SRM) was purchased from National Institute of Standards and Technology (NIST), working solution of $\mathrm{Cd}, \mathrm{Pb}, \mathrm{Cu}, \mathrm{Fe}$ and $\mathrm{Zn}$ were prepared from standard solution (1000 $\mu \mathrm{g} / \mathrm{mL}$, Merck). Immediately before use blanks were also prepared in the same manner as that of the samples.

Instrumentation. Hitachi Z-5000 Graphite and Flame Atomic Absorption Spectrophotometer with Zeeman background was used for the determination of $\mathrm{Cd}$ and $\mathrm{Pb}$, while essential $\mathrm{Fe}, \mathrm{Cu}$ and $\mathrm{Zn}$ were analysed by the flame atomic absorption spectrophotometer (FAAS).

Statistical analysis. Statistical analysis was done using Tukey's mean comparison test. All calculations were carried out by using Excel for Windows on the basis of linear equations (Table 2).

Quality control. The standard addition approach was adopted in order to avoid matrix interferences (Beavington et al., 2004) and appropriate dilutions were made prior to the analysis. The known amount of standards $(0.2,0.4,0.8 \mathrm{mg} / \mathrm{L})$ was spiked using replicate 6 samples of each, and applied both digestion methods. For quality control, standard solutions of $\mathrm{Cd}, \mathrm{Pb}, \mathrm{Zn}$, $\mathrm{Cu}, \mathrm{Fe}$, were analyzed in every 5 samples to check for the recoveries (Yap et al., 2004).

Mean values of triplicate sample were subjected to calculation and correlation matrices were produced to examine the inter-relationships between the investigated metal concentrations of the fish samples.

\section{Results and Discussion}

The metal concentration $(\mu \mathrm{g} / \mathrm{g})$ of $\mathrm{Cd}, \mathrm{Pb}, \mathrm{Zn}, \mathrm{Cu}$ and $\mathrm{Fe}$ is presented in Table 1 for 5 fish and 3 shrimp species. Relative concentration of metals detected in 5 fish species and 3 shrimp species have shown a relationship between metals and among species variation in case of shrimp as well as fish (Fig. 1-2). Results show that concentration of $\mathrm{Cd}$ varied from 0.017 up to the maximum 0.120 with a mean value $1.25 \mu \mathrm{g} / \mathrm{g}$ (Table 1) which is higher than $0.32-0.66 \mu / \mathrm{g}$ found in Saudian tuna (Voegborlo et al., 1999) and $0.35 \mu \mathrm{g} / \mathrm{g}$ in fish from Arabian sea (Tariq et al., 1993). This is due to recent increase in metal pollution in Arabian sea from where these fish were caught and may be due to interspecies differences (uptake, deposition or excretion). Similarly, the level of $\mathrm{Pb}$ ranged from 0.122 to 1.018 with a mean of $0.63 \mu \mathrm{g} / \mathrm{g}$ which is also higher than average permissible values however $\mathrm{Zn}, \mathrm{Cu}$ and $\mathrm{Fe}$ were found within the permissible limits (EC, 2005). Metal contents along with relevant statistical data means with standard deviation are given in Table 2. The coefficient of variation were collectively calculated for fish and shrimp samples and only two elements were strongly correlated. The significant correlation coefficient $(\mathrm{r}<1.00)$ was found between $\mathrm{Pb}, \mathrm{Cu}$ and $\mathrm{Cd}$.

Good recoveries (\%) 97, 96, 98, 99 and 101 for $\mathrm{Cd}, \mathrm{Pb}$, $\mathrm{Fe}, \mathrm{Zn}$ and $\mathrm{Cu}$, respectively of spiked sample demonstrates the accuracy of the method used. Detection limits were calculated as for $0.001 \mu \mathrm{g} / \mathrm{g}, \mathrm{Cd} 0.003 \mu \mathrm{g} / \mathrm{g}$ for $\mathrm{Pb}$ and $0.005 \mu \mathrm{g} / \mathrm{g}$ for $\mathrm{Fe}$ (Table 2).

The metal content in all three species were found lower than detected in other countries, as in Bangladesh the 
level of $\mathrm{Pb}$ and $\mathrm{Cd}$ was 0.8-1.3 and 0.2-0.4 in P. monodon (Fig. 1-2) (Hossain and Khan, 2001).

In case of shrimp, all metals' concentrations were found in lower range as compared to selected fish species (Table 1). Level of contamination of any metal in marine fauna depends upon accumulation of that metal. The level of $\mathrm{Cu}$ in the liver was found to be higher than the muscle (Papagiannis et al., 2004). The maximum concentration of $\mathrm{Pb}$ and $\mathrm{Cd}$ was 0.489 and $2.457 \mu \mathrm{g} / \mathrm{g}$, respectively in $P$. longirostris which is lower than observed in the same species of India that is 62.5 for $\mathrm{Pb}$ (Mitra et al., 2000) and 2.50 for $\mathrm{Cd}$ in P. monodon (Mitra et al., 2012). Metals accumulate differentially in fish organs and cause serious health hazards to humans. For this reason, the problem of fish and other aquatic contamination by toxic metals has received much attention (Mansour and Sidky, 2002).

The results of the analysis indicate that concentration of the $\mathrm{Cd}$ varied from 0.02 to 0.12 with a mean of 0.0 $08 \mu \mathrm{g} / \mathrm{g}$ in $5 \mathrm{species}$ of fish and in shrimp ranged from a mean of $0.21-0.25$. The concentration of $\mathrm{Cd}$ in all samples of fish and shrimp analysed were below the permissible limit of $0.05 \mathrm{mg} / \mathrm{kg}$ limit of $\mathrm{Cd}$ set by European Union (EU, 2001) and also lower than 3.70 ( $\mu \mathrm{g} / \mathrm{g}$ wet wt.) recommended limit by United States Food and Drug Administration (USFDA, 1993b).

The mean concentration of lead was found to be 0.12 $1.012 \mu \mathrm{g} / \mathrm{g}$ and shrimp samples were much below the

Table 1. Toxic and essential element contents in fish and shrimp species from coastal regions of Karachi

\begin{tabular}{|c|c|c|c|c|c|c|}
\hline \multirow{2}{*}{$\begin{array}{l}\text { Fish and shrimp } \\
\text { species }\end{array}$} & \multirow{2}{*}{$\begin{array}{l}\text { Common } \\
\text { names }\end{array}$} & $\mathrm{Cd}$ & $\mathrm{Pb}$ & $\mathrm{Zn}$ & $\mathrm{Cu}$ & $\mathrm{Fe}$ \\
\hline & & \multicolumn{4}{|c|}{ ( $\mu \mathrm{g} / \mathrm{g}$ wet weight) } & \\
\hline \multicolumn{7}{|l|}{ Fish species } \\
\hline \multirow{2}{*}{ Liza vaigiensis } & Mullet & $0.121-0.233$ & $0.095-0.270$ & $1.012-1.185$ & $0.490-0.635$ & $0.014-1.102$ \\
\hline & $0.030 \pm 0.05$ & $0.160 \pm 0.07$ & $0.007 \pm 0.04$ & $0.160 \pm 0.07$ & $0.180 \pm 0.07$ & \\
\hline \multirow[t]{2}{*}{ Sardinella albella } & Tarli & $0.022-0.235$ & $0.090-0.335$ & $0.026-1.635$ & $0.502-0.585$ & $1.010-1.635$ \\
\hline & $0.040 \pm 0.22$ & $0.157 \pm 0.07$ & $1.530 \pm 0.07$ & $0.007 \pm 0.04$ & $0.125 \pm 0.050$ & \\
\hline \multirow[t]{2}{*}{ Scomberomorus guttatus } & Surmai & $0.027-0.031$ & $0.097-0.321$ & $0.026-0.031$ & $0.057-0.491$ & $0.613-1.321$ \\
\hline & $0.026 \pm 0.01$ & $0.122 \pm 0.03$ & $1.026 \pm 0.01$ & $0.006 \pm 0.05$ & $0.140 \pm 0.039$ & \\
\hline \multirow[t]{2}{*}{ Pomadasys olivaecum } & Dohtar & $0.02-0.250$ & $\mathrm{nd}^{*}$ & $1.01-0.050$ & $0.055-0.680$ & $1.015-1.421$ \\
\hline & $0.017 \pm 0.06$ & & $1.018 \pm 0.08$ & $0.008 \pm 0.07$ & $0.131 \pm 0.048$ & \\
\hline \multirow[t]{2}{*}{ Otolithes ruber } & Mushka & $0.036-0.343$ & $1.02-0.450$ & $0.045-0.076$ & $0.054-0.665$ & $0.692-1.141$ \\
\hline & $0.120 \pm 0.03$ & $1.018 \pm 0.07$ & $0.008 \pm 0.07$ & $0.050 \pm 0.01$ & $0.158 \pm 0.07$ & \\
\hline \multicolumn{7}{|l|}{ Shrimp species } \\
\hline \multirow[t]{2}{*}{ Penaeus penicillatus } & Jaira or & 0.205 & 0.395 & 0.931 & 0.515 & 1.024 \\
\hline & redtail prawn & $(0.126-0.204)$ & $(0.216-0.384)$ & $(0.560-1.302)$ & $(0.316-0.764)$ & $(0.659-1.389)$ \\
\hline \multirow[t]{2}{*}{ Penaeus monodon } & Blacktiger & 0.215 & 0.415 & 0.915 & 0.415 & 1.011 \\
\hline & shrimp & $(0.124-0.254)$ & $(0.416-0.494)$ & $(0.516-1.264)$ & $(0.416-0.564)$ & $(0.547-1.089)$ \\
\hline \multirow[t]{2}{*}{ Palaemon longirostris } & Roshma prawn & 2.457 & 0.489 & 0.895 & 0.546 & 0.956 \\
\hline & (English) & $(2.192-2.322)$ & $(0.454-0.519)$ & $(0.496-1.364)$ & $(0.485-0.606)$ & $(0.659-1.389)$ \\
\hline
\end{tabular}

nd $=$ not detected

Table 2 . Metal contents along with relevant statistical parameters in fish and shrimp samples

\begin{tabular}{lllllll}
\hline \hline Metals & $\begin{array}{l}\text { Detection limit } \\
(\mu \mathrm{g} / \mathrm{g})\end{array}$ & Range & $\mathrm{X}$ & $\pm \mathrm{SD}$ & $\mathrm{CV} \%$ & $\begin{array}{l}\text { *Permissible limits } \\
(\mu \mathrm{g} / \mathrm{g} \text { wet wt. }\end{array}$ \\
\hline $\mathrm{Cd}$ & 0.001 & $0.017-2.457$ & 1.25 & 1.24 & 25.8 & 0.05 \\
$\mathrm{~Pb}$ & 0.003 & $0.122-1.018$ & 0.63 & 0.63 & 41.3 & 0.20 \\
$\mathrm{Zn}$ & 0.005 & $0.008-1.530$ & 0.77 & 0.76 & 39.8 & 120.0 \\
$\mathrm{Cu}$ & 0.003 & $0.006-0.546$ & 0.28 & 0.28 & 24.8 & 30 \\
$\mathrm{Fe}$ & 0.005 & $0.956-1.024$ & 1.47 & 1.44 & 41.3 & 125.0 \\
\hline \hline
\end{tabular}

* = Maximum acceptable levels of heavy metals in fish muscles (EC, 2005) 


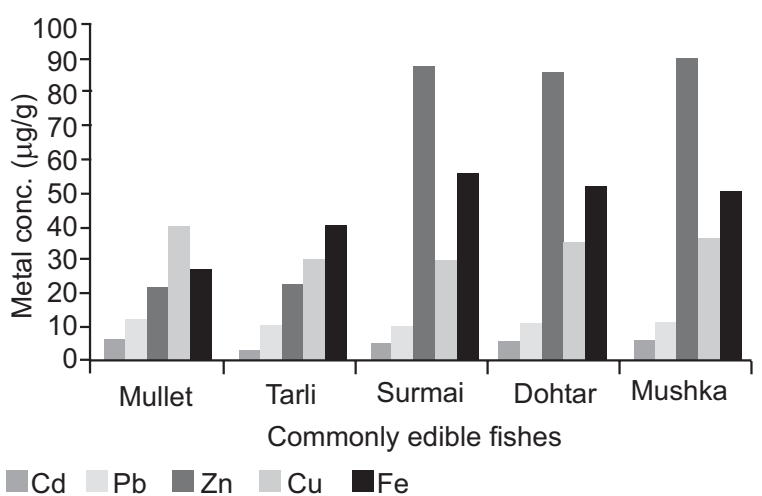

Fig. 1. Relative concentration of metals detected in fish meat as part of meal.

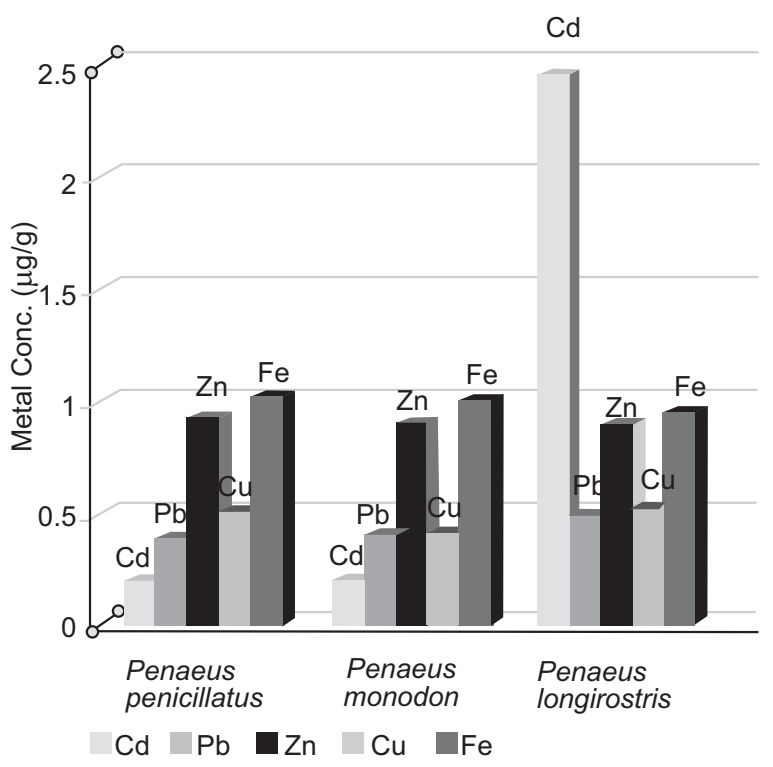

Fig. 2. Leave of toxic metals in shrimp species.

permissible limit. For $\mathrm{Cu}(\mu \mathrm{g} / \mathrm{g})$ Canadian Food Standard (2011) is 100, acceptable Hungarian standard 60, the range of international standard is 10-100. Turkish range of international standard is 10-100, limit 20 (Papagiannis et al., 2004), USEPA (2000) limit 120, and toxic limit for fish by FAO (1983) is $30 \mathrm{mg} / \mathrm{kg}$. Cu concentration in all fish and shrimp samples analyzed was below the corresponding authorized limits.

The potential hazards of metals transferred to humans are probably dependent on the amount of fish/shrimp consumed by an individual. Average intake of fish in Pakistan is plus $2 \mathrm{~kg}$ per capita per annum according to National Policy and Strategy for Fisheries and Aquaculture Development in Pakistan (NPSFAD, 2007). The estimates of JECFA (2003) recommended provisional tolerable total weekly intake (PTWI) for
$\mathrm{Pb}$ as $1.5 \mathrm{mg} /$ week and JECFA (2000) regarding provisional daily intake (PTDI) for $\mathrm{Pb}$ as $25 \mu \mathrm{g} / \mathrm{kg}$ which is equivalent to $0.21 \mathrm{mg} /$ day. The dietary intake of fish and prawn estimated from the present study is well below these dietary intakes and the tested fish and prawn samples therefore do not represent any known health risk to local population. If the consumer take the prawn or fish for 7 consecutive days, then he will consume $1.20 \mu \mathrm{g} \mathrm{Cd}(1.20 \times 7$ days $)$ from fish or 1.50 $\mu \mathrm{g} \mathrm{Cd}(0.147 \times 7$ days $)$ from prawn than expected $\mathrm{Cd}$ intake is lower than the recommended limit for provisional tolerable weekly intake of $\mathrm{Cd}$ (6.70-8.30 $\mu \mathrm{g} /$ adult) recommended by JECFA (2003) which is $490 \mu \mathrm{g}$.

A linear regression correlation test was performed to investigate the metal to metal correlation studies. Correlations between metal concentrations in fish are presented in Table 3. A positive correlation exists between $\mathrm{Cu} \& \mathrm{Zn}, \mathrm{Fe} \& \mathrm{Cu}, \mathrm{Pb} \& \mathrm{Zn}, \mathrm{Pb} \& \mathrm{Cu}, \mathrm{Pb} \&$ $\mathrm{Fe}, \mathrm{Cd} \& \mathrm{Zn}$ and $\mathrm{Cd} \& \mathrm{Cu}$ with corresponding 'r' values of $0.137,0.275,0.051,0.192,0.521$ and 0.011 , respectively. A negative correlation exists between $\mathrm{Fe} \& \mathrm{Zn}, \mathrm{Cd} \& \mathrm{Fe}$ and $\mathrm{Cd} \& \mathrm{~Pb}$ with corresponding ' $r$ ' values of $-0.445,-0.547$ and -0.265 , respectively. The significant correlation was found positively between $\mathrm{Cd} \& \mathrm{Zn}$ and negatively between $\mathrm{Cd} \& \mathrm{Fe}$ only (P-value $<0.05)$ (Table 3).

Levels of heavy metals (copper, cadmium, lead, iron and zinc) in tissues of $P$. penicillatus were found to be below the acceptable limits of heavy metal pollution in fish and shell fish (FAO/WHO, 1984). Mean levels of lead (Pb), and cadmium $(\mathrm{Cd})$ were observed to be higher than the world standard but not significantly higher. The joint Food and Agricultural Organization/World Health Expert Committee on food additives has suggested a provisional tolerable intake of $400-500 \mu \mathrm{g} \mathrm{Cd} /$ week for man and allowed $\mathrm{Pb}$ intake of $3 \mathrm{mg} /$ week. This shows that the levels of lead and cadmium in the fishing areas of Karachi

Table 3. Pearson correlation coefficient among the metals content found in fishery samples

\begin{tabular}{llllll}
\hline \hline Elements & $\mathrm{Zn}$ & $\mathrm{Cu}$ & $\mathrm{Fe}$ & $\mathrm{Pb}$ & $\mathrm{Cd}$ \\
\hline $\mathrm{Zn}$ & 1.000 & - & - & - & - \\
$\mathrm{Cu}$ & 0.137 & 1.000 & - & - & - \\
$\mathrm{Fe}$ & -0.445 & 0.275 & 1.000 & - & - \\
$\mathrm{Pb}$ & 0.051 & 0.192 & 0.231 & 1.000 & - \\
$\mathrm{Cd}$ & 0.521 & 0.011 & -0.547 & -0.265 & 1.000 \\
\hline \hline
\end{tabular}


Table 4. Metals concentration found in fish and shell fish of other countries

\begin{tabular}{llllllll}
\hline \hline Location & Species & $\mathrm{Zn}$ & $\mathrm{Cu}$ & $\mathrm{Pb}$ & $\mathrm{Cd}$ & $\mathrm{Fe}$ & References \\
\hline Karachi coast & Penaeus monodon & $0.516-$ & $0.416-$ & $0.416-$ & $0.124-$ & $0.547-$ & Present study- \\
& & 1.264 & 0.564 & 0.494 & 0.254 & 1.089 & $2011-12$ \\
Gulf of Fonseca & Penaeus monodon & $19-30$ & $2.1-$ & $0.035-$ & $0.002+0.03$ & - & Carbonell and \\
& & & 6.9 & 0.5 & & & Zona, 1994 \\
Bangladesh & Penaeus monodon & $24.2-$ & $12.2-$ & $0.8-$ & $0.2-0.4$ & - & Hossain and \\
& & 35.7 & 21.3 & 1.3 & & & Khan, 2001 \\
Indian Sundarbans & Penaeus monodon & $16-80$ & $10-60$ & $5.50-10$ & $\mathrm{BDL}-2.50$ & - & Mitra at al., 2012 \\
Winam Gulf, & Oreochromis niloticus, & $28.9-$ & $2.13-$ & $0.47-$ & $0.17-0.40$ & $31.4-$ & Ongeri et al., 2012 \\
Lake Victoria & Lates niloticus and & 409.3 & 8.74 & 2.53 & & 208.1 & \\
& Rastrineobola argentea & & & & & & \\
\hline \hline
\end{tabular}

coast are still tolerable and comparable with finding from other countries (Table 4).

Levels of various metals in fishery may vary due to a variety of factors. The results of present study indicate that, metal contaminated fish is consumed as food and neadst proper planning to control/check the supply of contaminants free fish. Maximum effort should be done to control marine pollution. Fish harbour hygiene condition and regular inspection of supply should be carried out. It must be implicated to have daily testing of fishery before they are supplied to the consumers. The concentrations of cadmium and lead previously reported were $0.006-0.088$ and $0.016-0.049 \mu \mathrm{g} / \mathrm{g}$ are similar to our results.

The specificity of concentrations of heavy metals irrespective of the locality of fish capture and the route of uptake of the metals has been reported by Eneji (2010). Varied level of contamination in the fish species is a reflection of different thresholds of metals which are a function of homeostasis. Species difference in heavy metals bioaccumulation could be linked to difference in feeding habits and behaviour of the species (Altindag and Yigit, 2005). It has been reported that fish species can accumulate heavy metals above the abiotic environment to incur bioaccumu-lation (Olaifa et al., 2004) and it is directly related to marine pollution status of the specific region, type of fishery and specific time period of breeding season.

Maximum mean $\mathrm{Pb}$ and $\mathrm{Cd}$ concentrations in Penaeus shrimp species in Trinidad are 22.84-26.78 $\mu \mathrm{g} / \mathrm{g}$ wet wt. which are below the maximum admissible limits of human consumption according to international and local standards thus safe for consumption although coastline of Gulf of Paris is considered to be highly polluted due to industrialized area of the region (Dhoray and Teelucksingh, 2007). In the present study, the maximum mean concentration was found as 2.457 and $0.489 \mu \mathrm{g} / \mathrm{g}$ which is also below the maximum residual limits of $\mathrm{Pb}$ and $\mathrm{Cd}$.

\section{Conclusion}

The present study clearly indicates low accumulation of heavy metals in the edible fishery of Karachi coast. Most of the metal concentrations (except $\mathrm{Pb}$ ) in the fish and shrimp samples analyzed were well within the permitted limits set by various authorities and therefore, does not poses any health risk. However, regular monitoring on heavy metals accumulation in fish and shrimp tissues by local agencies should be emphasized.

\section{Acknowledgement}

Authors are grateful to officers and supporting staff of Center for Environmental Studies, PCSIR-KLC for their support.

\section{References}

Altindag, A., Yigit, S. 2005. Assessment of heavy metal concentrations in the food web of Lake Beysehir Turkey. Chemosphere, 60: 552-556.

Beavington, F., Cawse, P. A., Wakenshaw, A. 2004. Comparative studies of atmospheric trace elements: Improvements in air quality near a copper smelter. Science of the Total Environment, 332: 39-49.

Carbonell, J.V., Zona, J.V. 1994. Toxicokinetic of copper in rainbow trout Oncorhynchus myksis. Aquatic Toxicology, 29: 213-221. 
CFIA, 2011. The Purpose of the Fish Products Standards and Methods Manual, Standard 3-General Fresh Frozen Finishing Product Standard. Canadian Guidelines for Chemical Contamination and Toxins in Fish and Fish Products. Canadian Food Inspection Agency, Canada.

Dhoray, S., Teelucksingh, S.S. 2007. The implication of ecosystem dynamics for fisheries management: A case study of selected fisheries in the Gulf of Paris, Trinidad. Journal of Environmental Management, 85: 415-428.

EU, 2006. Setting maximum levels for certain contaminants in foodstuffs. Commission Regulation (Ec) No. 1881/2006. Official Journal of the European Union, 364: 5-24.

Eneji, I. S. 2010. Spatial and Temporal Variation in the Heavy Metals Loading of River Benue in Makurdi Metropolitan Area, Ph. D. Thesis, Department of Chemistry University of Agriculture Makurdi, Nigeria.

EPA, 1989. Assessing Human Health Risks from Chemically Contaminated Fish and Shellfish: A Guidance Manual EPA-503/8-89-002, US Environmental Protection Agency, Washington. D.C., USA.

EU. 2001. Commission Regulation as regards heavy metals, Directive 001/22/EC, No: 466/2001.

EC, 2005. European Commission, Commission Regulation (EC) No 78/2005, Amending Regulation (EC) No 466/2001 as regards heavy metals L 16/43ñ45. 2005, www:http://eurlex.europa.eu/Lex UriServ/ LexUriServ.do?uri=OJ: L: 2005: 016: 0043: 0045: EN: PDF. Official Journal of the European Union. 48: 43-45.

FAO, 1992. FAO/WHO, Food Standard Programme. Codex Alimentarius Commission, vol. 1: pp. 114$190,2^{\text {nd }}$ edition.

FAO/WHO. 1984. List of maximum levels recommended for contaminants by the Joint FAO/WHO Codex Alimentarius Commission. Second Series CAC/FAL, Rome, vol. 3, pp.1-8.

FAO, 1983. World Food Security: A Reappraisal of the Concepts and Approaches. Director General's Report, Rome, Italy.

Hossain, M.S., Khan, Y.S.A. 2001. Trace metals in penaeid shrimp and spiny lobster from the Bay of Bengal. Science Asia, 27: 165-168.

JECFA, 2003. Joint FAO/WHO Expert Committee on Food Additives. Sixty- first Meeting. Summary and Conclusions., World Health Organization,
Geneva, Switzerland.

JECFA, 2000. Joint FAO/WHO Expert Committee on Food Additives. Fifty-fifth Meeting. Summary and Conclusions., World Health Organization, Geneva, Switzerland.

Levy, Y., Zeharoa, A., Grunebaum, M., Nitzan, M., Steinherz, R. 1985. Copper deficiency in infants fed cow milk. Journal of Pediatric, 106: 786-788.

Mansour, S.A., Sidky, M.M. 2002. Ecotoxicological studies.3. Heavy metals contaminating water and fish from Fayoum, Governorate, Egypt. Food Chemistry, 78: 15-22.

Mitra, A., Barua, P., Zaman, S., Banerjee, K. 2012. Analysis of trace metals in commercially important crustaceans collected from UNESCO protected world heritage site of Indian Sundarbans. Turkish Journal of Fisheries and Aquatic Sciences, 12: 53-66.

Mitra, A., Mitra, S., Hazra, S., Chaudri, A. 2000. Heavy metal concentrations in Indian Coastal fishes. Research Journal of Chemistry and Environment, 4: 35-37.

NPSFAD, 2007. National Policy and Strategy for Fisheries and Aquaculture Development in Pakistan. Ministry of Food, Agriculture and Livestock, Government of Pakistan, Islamabad, Pakistan.

Olaifa, F. E., Olaifa, A. K., Adelaja, A.A., Omolabi, A.G. 2004. Heavy metal contamination of Clarias gariepinus from a lake and fish farm in Ibadan, $\mathrm{k}$ Nigeria. African Journal of Biomedical Research, 7: 145-148.

Ongeri, D.M., Lalah, J.O., Wandiga, S.O., Schramm, K.W., Michal ke, B. 2012. Seasonal variability in cadmium, lead, copper, zinc and iron concentrations in the three major fish species, Oreochromis niloticus, Lates niloticus and Rastrineobola argentea in Winam Gulf, Lake Victoria: impact of wash-off into the lake. Bulletin of Environmental Contamination and Toxicology, 88: 166-171.

Papagiannis, L., Kagalou, L., Leonardos, J., Petridis, D., Kalfakakou, V. 2004. Copper and zinc in four fresh water fish species from lake Pamvotis (Greece). Environment International, 30: 357-362.

Storelli, M. M., Storelli, A., D'ddabbo, R., Marano, C., Bruno, R., Marcotrigiano, G.O. 2005. Trace elements in loggerhead turtles (Carettacaretta) from the eastern Mediterranean Sea: Overview and evaluation. Environmental Pollution, 135: 163-170.

Tariq, J., Jaffer, M., Ashraf, M., Moazzam, M. 1993. Heavy metal concentration in fish, shrimp, seaweed 
and water from Arabian Sea, Pakistan. Marine Pollution Bulletin, 26: 644-647.

Tariq, M., Islam, K.R., Muhammad, S. 2007. Toxic effets of heavy metals on early growth and tolerance of cereal crop. Pakistan Journal of Botany, 39: 451-462.

Turkmen, M., Turkmen, A., Tep E, Y., Töre, Y., Ates, A. 2009. Determination of metals in fish species from Aegean and Mediterranean Seas. Food Chemistry, 113: 233-237.

US EPA, 2000. Supplimentary Guidance for Conducting Health Risk Assessment of Chemical Mixture, EPA/630/R-00/002, August 2000, USA.

US FDA, 2003. Total Diet Study Statistics on Element Results. Washington, DC: US Food and Drug Administration Centre for Food Safety and Applied Nutrition, USA.

US FDA, 1993a. Guidelines for determining metric equivalent household measures. Food Labeling Guide, M.S. Food and Drug Administration, USA.

US FDA, 1993b. Guidance Documents for Trace Elements in Seafood. Food Drug Administration
Centre for Food Safety and Applied Nutrition, Washington. [on-line] http://vm.cfsan.fda.gov/frf/ guid-sf.html.

Varsha, M., Nidhi, M., Anurag, M., Singh, B., Sanjay, M. 2010. Effect of toxic metals on human health. The Open Nutraceuticals Journal, 3: 94-99.

Voegborlo, R.B., El-Methnani, A.M., Abedin, M.Z. 1999. Mercury, cadmium and lead content of canned tuna fish. Food Chemistry, 67: 341-345.

Yap, C.K., Ismail, A., Tan, S.G. 2004. Heavy metal (Cd, $\mathrm{Cu}, \mathrm{Pb}$ and $\mathrm{Zn}$ ) concentrations in the green-lipped mussel Perna viridis (Linnaeus) collected from some wild and aquacultural sites in the west coast of Peninsular Malaysia. Food Chemistry, 84: 569-575.

Yilmaz, F., Ozdemir, N., Demirak, A., Tuna, A.L. 2007. Heavy metal levels in two fish species Leucis cuscephalus and Lepomis gibbosus. Food Chemistry, 100: 830-835.

Zachariadis, G.A., Sratis, J.A., Kaniou, I., Kalligas, G. 1995. Critical comparison of wet and dry digestion procedures of trace metal analysis of meat and fish tissues. Microchimica Acta, 119: 191-198. 